\title{
SISTEM INFORMASI PENJUALAN BERBASIS E-COMMERCE UNTUK MENGOPTIMALKAN PENJUALAN BATIK PADA TOKO AL-BAROKAH BATIK
}

\author{
Mas Dimas Satria Ananda ${ }^{1)}$, Ita Novita ${ }^{2)}$ \\ Program Studi Sistem Informasi, Fakultas Teknologi Informasi, Universitas Budi Luhur \\ J1. Raya Ciledug, Petukangan Utara, Kebayoran Lama, Jakarta Selatan 12260 \\ E-mail : withyourlife24@ gmail.com ${ }^{1)}$, ita.novita@budiluhur.ac.id $^{2)}$
}

\begin{abstract}
Abstrak
Al-Barokah Batik merupakan suatu toko yang bergerak dalam bidang penjualan baju batik dewasa. AlBarokah Batik masih memiliki kekurangan dalam menunjang proses transaksi penjualan produk. Dan juga kurang optimalnya transaksi yang dilakukan, seperti media informasi berupa facebook dan instagram yang digunakan hanya untuk menampilkan produk-produk yang tersedia pada Al-Barokah Batik sehingga customer yang ingin membeli harus datang langsung ketoko. Untuk itu di perlukan sebuah website e-commerce yang dapat memberikan informasi mengenai produk dan kemudahan transaksi kepada customer. Metode bussines model canvas dipilih untuk digunakan dalam pembuatan e-commerce dengan tujuan untuk meningkatkan penjualan batik pada AlBarokah Batik. Dari permasalahan tersebut maka dibangunlah sebuah website penjualan online yang diharapkan dapat membantu Al-Barokah Batik dalam meningkatkan penjualan produk kepada customer.
\end{abstract}

Kata kunci: E-commerce, Bussines Model Canvas (BMC), Penjualan Batik

\section{PENDAHULUAN}

E-Commerce merupakan salah satu konsep yang cukup berkembang dalam bidang teknologi informasi. Penerapan e-commerce lebih banyak memberikan keuntungan jika dibandingkan dengan konsep belanja yang konvensional, diantaranya semua informasi yang diinginkan customer dapat diakses lebih detail, cepat tanpa dibatasi tempat dan waktu, dan proses transaksi pun bisa dilakukan menjadi jauh lebih mudah. Sehingga dengan penerapan sistem ini akan sangat mempermudah dan lebih menguntungkan banyak pihak, baik dari pihak customer, maupun penjual. Oleh sebab itu banyak jasa yang menawarkan aplikasi e-commerce dengan fungsi yang dapat disesuaikan oleh kebutuhan toko itu sendiri. Sehingga dapat meningkatkan penjualan dan dapat memudahkan customer untuk mendapatkan informasi produk ataupun melakukan aktivitas belanja.

Al-Barokah Batik merupakan suatu toko yang bergerak dalam bidang penjualan baju batik dewasa. Al-Barokah Batik memiliki kekurangan dalam menunjang proses transaksi penjualan batik, sehingga transaksi yang dilakukan masih belum optimal. Saat ini, Al-Barokah Batik belum memiliki website untuk mempromosikan dan menjual produknya. Adapun media informasi yang digunakan seperti Facebook dan Instagram yang digunakan hanya untuk menampilkan produk-produk yang tersedia sehingga customer yang ingin membeli harus datang langsung ketoko.

Penelitian ini bertujuan untuk mengoptimalkan penjualan batik pada Toko Al-Barokah Batik dengan menggunakan website e-commerce. Dan juga mampu memberikan informasi ataupun memudahkan customer dalam melakukan aktivitas berbelanja di Toko Al-Barokah Batik.
Masalah yang terjadi pada penelitian ini adalah kurang optimalnya informasi yang didapat customer mengenai detail produk ataupun produk terbaru. Belum tersedianya media informasi yang dapat memudahkan pemesanan oleh customer terhadap produk yang dijual. Dan sistem penjualan masih bersifat manual, yaitu pembeli harus datang lansung ke toko sehingga menyulitkan customer yang berada jauh dari toko. Berdasarkan permasalahan diatas penulis mengusulkan untuk merancang sistem penjualan berbasis website e-commerce, dengan memanfaatkan teknologi internet dalam penjualan sehingga dapat diakses kapan saja dan dimana saja oleh konsumen.

\section{PENELITIAN SEBELUMNYA \\ a. Handayani (2018)}

Menurut penelitian dari (Handayani, 2018) dengan judul "Perancangan Sistem Informasi Penjualan Berbasis E-Commerce Studi Kasus Toko Kun Jakarta". Permasalahan yang sering dihadapi pada Toko Kun Jakarta adalah media promosi hanya menggunakan spanduk, penjualan masih sebatas offline, penyimpanan data dan pencetakan laporan masih berupa pencatatan dalam bentuk arsip. Hasil dan kesimpulan dari penelitian ini adalah website penjualan berbasis e-commerce dapat dijadikan sebagai media promosi, mempermudah dalam pengolahan data dan pencetakan laporan tidak lagi memerlukan pencatatan dalam bentuk arsip [1]

b. A.A. Mahendra (2015)

Menurut penelitian dari (A.A. Mahendra, 2015) dengan judul "Pembuatan Website E-Commerce pada toko mainan dan Figure Hazashop Semarang" 
Hazashop merupakan sebuah toko yang menjual berbagai macam mainan dan Figure.permasalahan yang dihadapi pada Hazashop adalah transaksi yang dilakukan saat ini melalui media situs pertemanan facebook dan BBM. Tujuan dari penelitian adalah menghasilkan website E-commerce pada Toko Mainan dan figure hazashop yang dapat membantu dalam menjualkan dan mempromosikan barang kepada konsumen melalui internet [2].

c. Pradana (2015)

Penelitian oleh Pradana (2015) Jurnal Neo-Bis Vol. 9 No. 2, Desember 2015, dengan judul "Klarisifikasi jenis-jenis bisnis e-commerce di Indonesia". Tujuan dari penelitian ini adalah memberi gambaran konseptual mengenai jenis-jenis $e$ commerce di Indonesia. Dengan aktivitas bisnis secara e-commerce, maka perusahaan dapat memperluas aktivitas dan menjangkau konsumen dengan lebih mudah. Dan juga proses transaksi yang selama ini sifatnya konvensional menjadi lebih modern dengan tersedianya transaksi online [3].

\section{METODE PENELITIAN}

\subsection{Metode Pengumpulan Data}

Data yang dikumpulkan dalam penelitian digunakan untuk menguji hipotesis atau menjawab pertanyaan yang telah dirumuskan. Pengumpulan data ini dilakukan untuk memperoleh informasi yang dibutuhkan dalam rangka mencapai tujuan penelitian. Berikut ini adalah metode pengumpulan data penelitian yang telah dilakukan penulis yaitu:

a. Wawancara

Wawancara juga merupakan suatu cara pengumpulan data yang digunakan untuk memperoleh informasi langsung dari sumbernya. Yaitu dengan cara mengajukan berbagai pertanyaan kepada pengurus Toko Al-Barokah Batik. Dari hasil wawancara ini penulis mendapatkan bagaimana alur proses bisnis penjualan yang berjalan pada Toko Al-Barokah Batik.

b. Observasi

Pengamatan atau observasi adalah metode pengumpulan data dengan melakukan pengamatan langsung kepada objek yaitu dengan mengamati langsung kegiatan atau proses transaksi yang terjadi pada Toko AlBarokah Batik yang berada di Lt. Dasar Blok B No.99 ITC Cipulir.

c. Analisa dokumen

Teknik ini merupakan kegiatan mengumpulkan seluruh dokumen yang berhubungan dan digunakan dalam kegiatan penjualan pada Toko Al-Barokah Batik.
Kemudian menganalisa dokumen dokumen tersebut untuk mendapatkan informasi.

d. Studi Literatur

Studi literatur dilakukan oleh penulis dengan melakukan pencarian dan mengumpulkan berbagai referensi yang sesuai dengan permasalahan, untuk dijadikan sebagai rujukan dalam penulisan.

\subsection{Bussiness Model Canvas}

Untuk membantu Toko Al-Barokah Batik dalam membuat model bisnis dibuatlah kerangka kerjanya yang terlihat pada Gambar 1 .

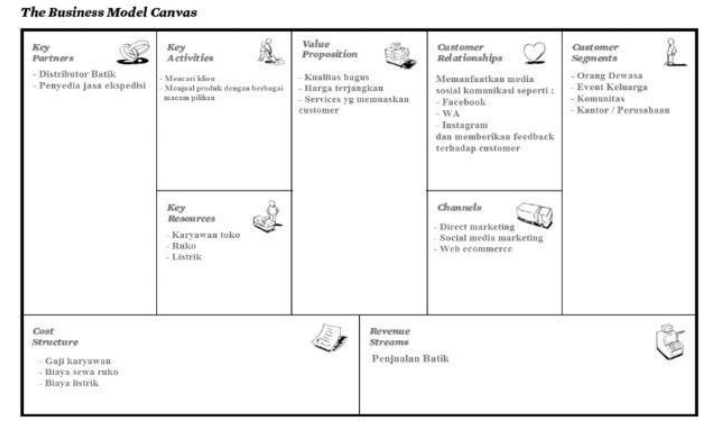

Gambar 1. BMC

Adapun penjelasannya adalah sebagai berikut:

a. Customer Segments

Toko Al-Barokah Batik melakukan komunikasi terhadap customer, dengan memanfaatkan media sosial, untuk memberikan informasi tentang produk batik terbaru. Customer yang menjadi sasaran penjualan adalah orang dewasa, komunitas, atau untuk kebutuhan acara.

b. Value Propositions

Merupakan nilai yang Al-Barokah Batik tawarkan kepada customer. Menawarkan batik berkualitas, lengkap dan memberikan harga yang memuaskan customer.

c. Channels

Al-Barokah Batik menggunakan media sosial seperti Facebook, Whatsapp, Instagram sebagai media promosi yang berjalan pada saat ini, website e-commerce yang juga digunakan sebagai media promosi sekaligus media penjualan yang baru dan toko fisik sebagai media penjualan offline untuk customer.

d. Customer Relationships

Al-Barokah Batik melakukan komunikasi terhadap customer, dengan memanfaatkan media sosial, untuk memberikan informasi tentang produk batik terbaru.

e. Revenue Streams

Cara mendapatkan keuntungan. AlBarokah Batik mendapatkan penghasilan dengan menjual berbagai macam batik. 


\section{f. Key Activities}

Aktivitas yang berhubungan dengan produktivitas bisnis yang berkaitan dengan sebuah produk dengan melakukan promosi dan melakukan penjualan produk batik.

g. Key Resources

Sumber daya yang dibutuhkan untuk menunjang kegiatan pada Al-Barokah Batik adalah beberapa sumber daya seperti bangunan ruko, karyawan, listrik, internet, dan layanan server.

h. Key Partnerships

Pihak-pihak yang berhubungan pada AlBarokah Batik yang berguna untuk memudahkan aktivitas bisnis yang berjalan. Key Partnetships pada Al-Barokah Batik adalah penyedia jasa ekspedisi dan distributor batik

i. Cost Structure

Pengeluaran yang dibutuhkan untuk menjalani bisnis ini. Yaitu sewa bangunan ruko, listrik, gaji karyawan, sewa hosting dan domain, bayar internet.

\section{HASIL DAN PEMBAHASAN}

\subsection{Proses Bisnis Usulan}

Pada proses bisnis usulan yang diusulkan kepada Toko Al-Barokah Batik peneliti menuangkan dalam bentuk activity diagram.

\section{1) Proses Bisnis Pemesanan}

Customer dapat melakukan pemesanan apabila terdapat produk pada keranjang belanja, customer menuju halaman keranjang belanja customer dapat melakukan pilih alamat untuk mengganti alamat yang lain, customer memilih kurir lalu mengklik tombol pilih metode pembayaran jika kuantitas pada keranjang melebihi stok yang tersedia maka sistem akan mengirim notifikasi kepada customer bahwa kuantitas melebihi stok, jika tidak sistem akan menampilkan popup berisi review order dan total pembayaran, kemudian klik lanjut, lalu customer memilih metode pembayaran, dan klik tombol lanjutkan pembayaran, sistem akan membuat pesanan dengan status menunggu pembayaran lalu mengirim email dan notifikasi kepada customer bahwa pesanan telah dibuat, kemudian customer akan dibawa ke halaman detil transaksi. Activity diagram proses pemesanan dalam dilihat pada Gambar 3 .

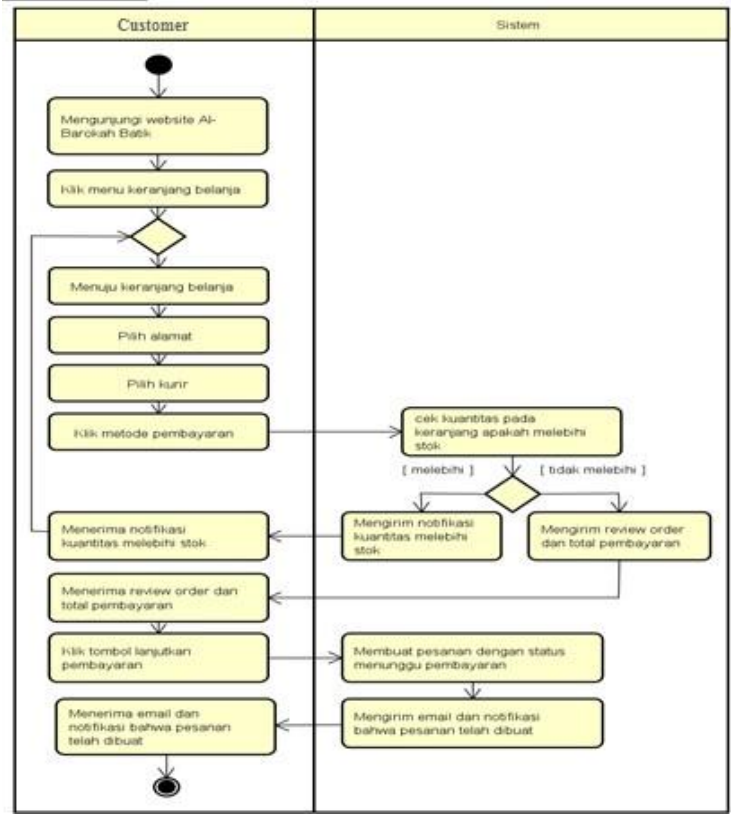

Gambar 3. Activity Diagram Proses Pemesanan

2) Proses Bisnis Pembayaran

Customer mengunjungi Website AlBarokah Batik. Lalu klik menu transaksi kemudian klik detil pada transaksi yang ingin dibayar. Kemudian sistem akan menampilkan review order, klik pada tombol lihat no rekening / lihat qr kode untuk informasi mengenai total pembayaran yang harus dibayar dan petunjuk pembayaran. Setelah customer melakukan pembayaran, sistem akan mengecek apakah pembayaran telah masuk, jika belum sistem tidak akan mengubah status pemesanan, jika telah masuk sistem akan mengubah status pemesanan menjadi dibayar lalu mengirim email kepada customer bahwa pembayaran berhasil dan mengirim email kepada admin bahwa ada pesanan yang masuk. Untuk activity diagramnya terlihat pada Gambar 4. 


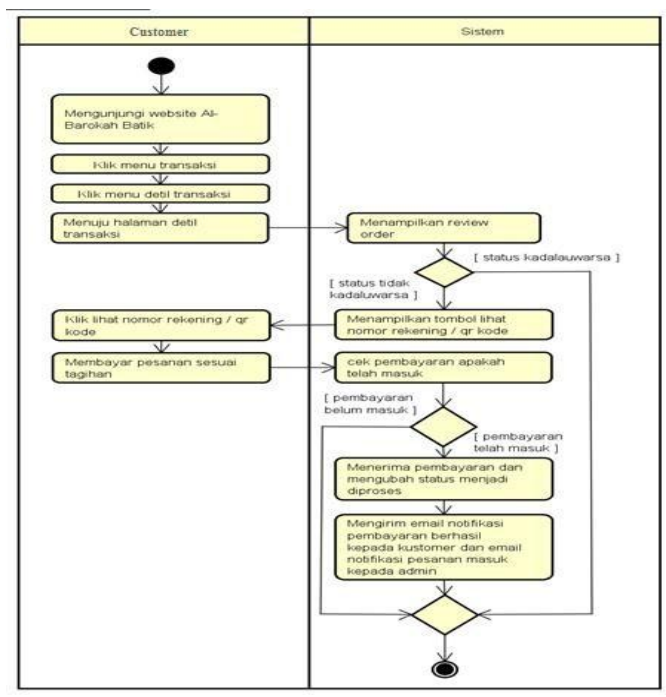

Gambar 4. Activity Diagram Proses Pembayaran

\subsection{Aturan Bisnis}

Adapun aturan bisnis yang diterapkan pada Al-Barokah Batik mengenai seluruh kegiatan bisnis yang berlangsung adalah sebagai berikut :

a. Customer harus membayar pemesanan $1 \times 24$ jam atau 1 hari.

b. Barang yang sudah dikirim tidak dapat ditukarkan kembali.

c. Pemesanan secara online akan diproses apabila customer telah melakukan pembayaran melalui website Al-Barokah Batik.

\subsection{Identifikasi Kebutuhan}

Tahapan selanjutnya adalah mengindentifikasi kebutuhan sistem dengan menggunakan use case diagram.

1) Use Case Diagram Transaksi

Pada Gambar 5 menjelaskan kebutuhan sistem untuk penginputan data transaksi. Aktor yang terlibat adalah customer, admin serta sistem.

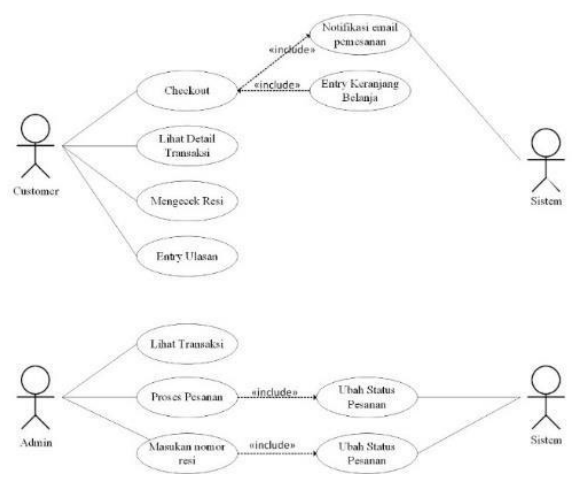

Gambar 5. Use Case Diagram Transaksi
2) Use Case Diagram Laporan

Pada Gambar 6 menjelaskan kebutuhan sistem yang mendukung untuk pengambilan keputusan pemilik toko dengan aktor yang terlibat adalah admin dan pemilik toko.

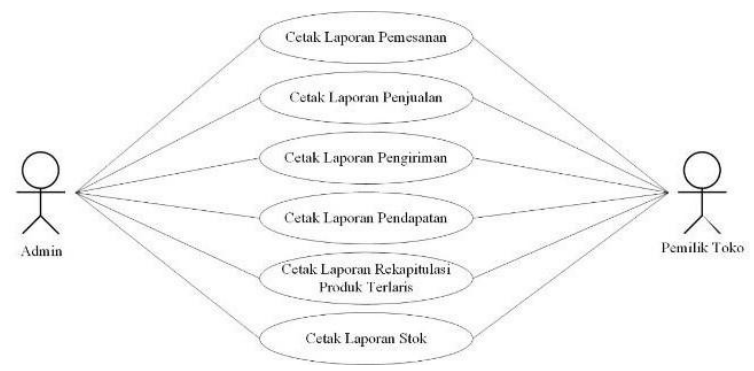

Gambar 6. Use Case Diagram Laporan

\subsection{Struktur Menu}

Pada Gambar 7 adalah struktur menu tampilan dari sisi admin. Menu utama terdiri dari Dashboard, Master, Transaksi dan Laporan.

Pada menu Master terdiri dari menu Produk, Detik Produk, Kategori dan Kurir. Untuk menu transaksi terdiri dari Lihat Data Transaksi yang berisi informasi Semua Transaksi, Belum Dibayar, Belum Diproses, Belum Dikirim, Sudah Dikirim maupun Kadaluwarsa.

Sedangkan untuk menu laporan terdiri dari Laporan Pemesanan, Laporan Penjualan, Laporan Pengiriman, Laporan Pendapatan, Laporan Produk Terlaris dan Laporan Stok.

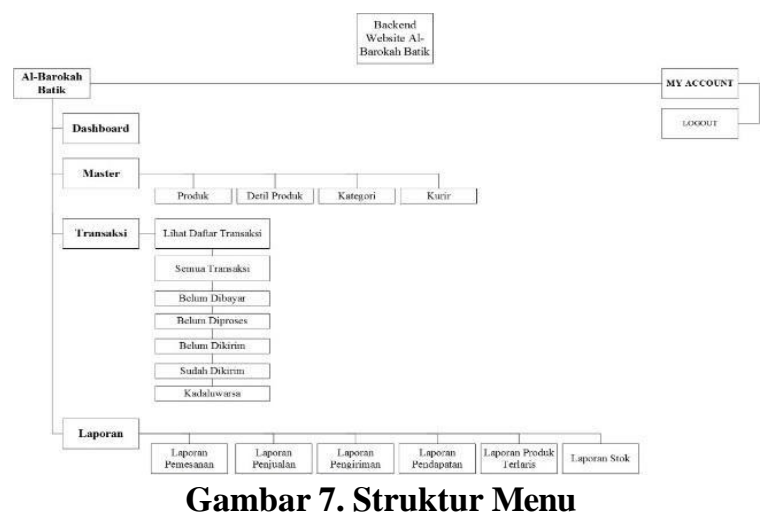

\subsection{Class Diagram}

Pada gambar 8 menjelaskan class diagram yang penulis gunakan sebagai struktur basis datanya. 


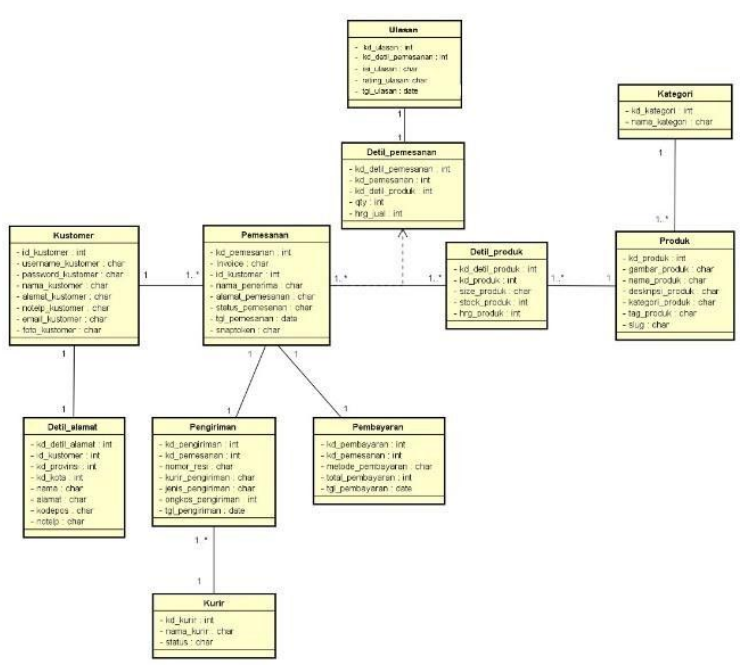

Gambar 8. Class Diagram

\subsection{Rancangan Layar}

Tahapan selanjutnya berdasarkan desain class diagram yaitu membuat rancangan layar. Untuk rancangan layar utama pada Gambar 9 memperlihatkan rancangan layar home dari sisi customer. Customer bisa melihat informasi produk dari Al-Barokah Batik baik produk terbaru maupun terlaris.

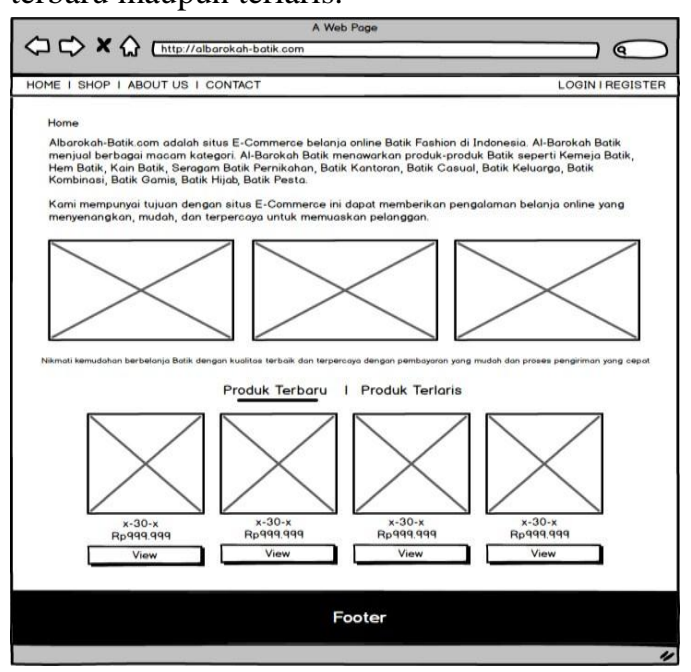

Gambar 9. Rancangan Layar Home

Untuk pemesanan produk yang dilakukan customer terlihat pada Gambar 10. Customer memilih produk, ukuran serta jumlah yang ingn dipesan.

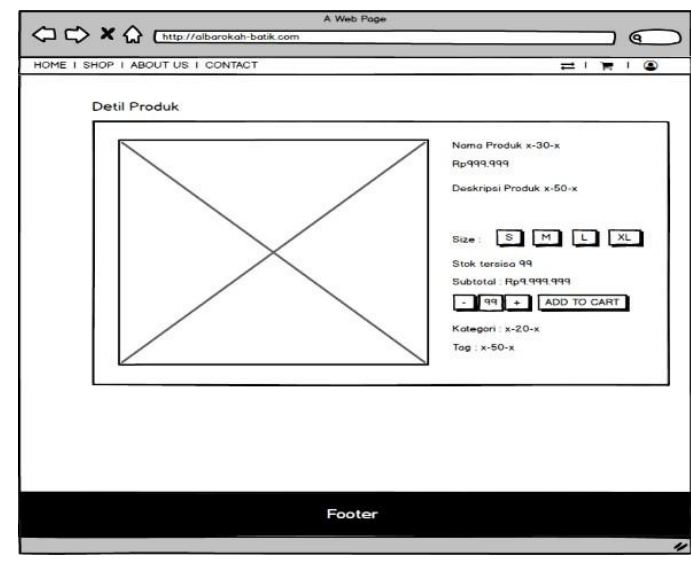

Gambar 10. Rancangan Layar Pemesanan

Sedangkan untuk melihat rincian produk yang dipesan serta total pembayaran terlihat pada Gambar 11.

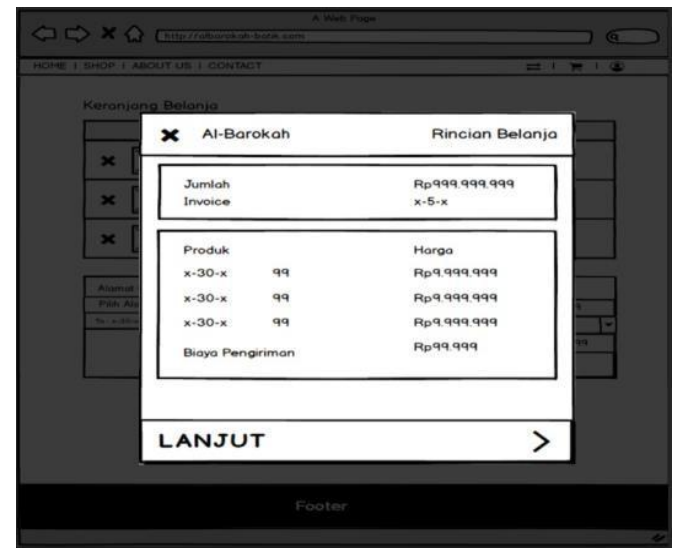

Gambar 11. Rancangan Layar Pembayaran

\section{KESIMPULAN}

Berdasarkan hasil pengamatan dan analisa yang dilakukan pada penelitian ini, maka didapatkan kesimpulan yaitu dengan menggunakan website e-commerce customer lebih mudah mendapatkan informasi mengenai detil produk maupun produk terbaru, memberikan kemudahan berbelanja bagi customer yang berada jauh dari toko dan juga mempermudah pembayaran karena dapat dilakukan secara online.

\section{DAFTAR PUSTAKA}

[1] S. Handayani, "Perancangan Sistem Informasi Penjualan Berbasis E-Commerce Studi Kasus Toko Kun Jakarta," Ilk. J. Ilm., vol. 10, no. 2, hal. 182, 2018.

[2] A. A. Mahendra, "Pembuatan Website E-Commerce Pada Toko Mainan Dan Figure Hazashop Semarang," Naskah Publ., hal. 15, 2015.

[3] M. Pradana, "Klasifikasi Jenis-Jenis Bisnis ECommerce Di Indonesia", Jurnal Neo-Bis, vol.. 9, no.2, hal. 32-40, 2015. 